\title{
Habitat use, size structure and sex ratio of the spot-legged turtle, Rhinoclemmys punctularia punctularia (Testudines: Geoemydidae), in Algodoal-Maiandeua Island, Pará, Brazil
}

\author{
Manoela Wariss ${ }^{1}$, Victoria Judith Isaac ${ }^{2} \&$ Juarez Carlos Brito Pezzuti ${ }^{1}$ \\ ${ }^{1}$ Núcleo de Altos Estudos Amazônicos, Sala 01, Setor Profissional, Universidade Federal do Pará, Campus Universitário do \\ Guamá, Rua Augusto Corrêa, nº 1 - CEP: 66.075-110, Belém, Pará, Brasil; manuwariss@yahoo.com.br, juca@ufpa.br \\ ${ }^{2}$ Laboratório de Biologia Pesqueira e Manejo de Recursos Aquáticos, Instituto de Ciências Biológicas, Universidade \\ Federal do Pará, Av. Perimetral Nº 2651, CEP 66077-830, Belém, Pará, Brasil; biologiapesqueira@ yahoo.com.br
}

\author{
Received 17-II-2011. C Corrected 30-V-2011. Accepted 29-VII-2011.
}

\begin{abstract}
Rhinoclemmys punctularia punctularia is a semi-aquatic chelonian found in Northern South America. We analyzed the habitat use, size structure and sex ratio of the species on Algodoal-Maiandeua Island, a protected area on the Northeastern coast of the Brazilian state of Pará. Four distinct habitats (coastal plain lake, flooded forest "igapó", interdunal lakes, and tidal channels) were surveyed during the rainy (March and April) and dry (August and September) seasons of 2009, using hoop traps. For the analysis of population structure, additional data were taken in March and August, 2008. A total of 169 individuals were captured in flooded forest (igapó), lakes of the coastal plain and, occasionally, in temporary pools. Capture rates were highest in the coastal plain lake, possibly due to the greater availability of the fruits that form part of the diet of R. p. punctularia. Of the physical-chemical variables measured, salinity appeared to be the only factor to have a significant negative effect on capture rates. The sex ratio was only slightly biased to females, and did not vary between habitats or seasons. Straight carapace length was significantly larger in females, but did not vary between habitats. Overall, the evidence indicates that both biotic and abiotic factors like food availability, low current and salinity, influence the habitats selection and use by R. p. punctularia on Algodoal-Maiandeua Island. Rev. Biol. Trop. 60 (1): 413-424. Epub 2012 March 01.
\end{abstract}

Keywords: cheilonian, ecology, Rhinoclemmys punctularia punctularia, Amazonia.

The types of habitat used by an organism reflect a series of environmental variables, including food availability, protection from predators and the physical-chemical characteristics of the environment, which have a direct effect on the survival and reproductive success of the species. Since distinct types of habitats may determine different survival rates and population structure, species will select those habitats that favor the highest survival and reproductive rates (Block \& Brennan 1993, Krausman 1999). Freshwater turtles (Testudines) use a variety of habitats over the course of their life cycle, ranging from terrestrial sites for nesting and basking to aquatic environments for feeding and mating (Boyer 1965, Bury
1979, Portal et al. 2002). Studies of habitat use and population structure are essential for understanding the ecology and life history of a species, which includes both ontogenetic development and seasonal variation (Bury 1979).

In their extensive review, Moll \& Moll (2004) demonstrated that the principal factors determining the decline of many freshwater chelonian populations are the loss of habitats that result from anthropogenic impacts, and the over-exploitation. The establishment of protected areas and the development of management plans are essential for mitigation of these impacts on chelonian populations and the habitats they occupy, particularly concerning recuperation of threatened species that are in decline 
(Klemens 2000, Litzgus \& Mosseau 2004). Understanding the ecology of a species is essential for the development of efficient measures for the mitigation of the effects of anthropogenic impacts on natural populations. These data are necessary for the establishment of conservation strategies and public policies that are not only effective, but also consistent with the ecological characteristics of the target species (Heppell \& Crowder 1996, Klemens 2000).

Most present-day studies of chelonians involve populations that inhabit environments which have already suffered some level of anthropogenic impact, resulting in changes in population structure, sex ratio, and even local extinction (Gibbons et al. 2000, Freitas et al. 2003, Marchand \& Litvaitis 2004, Congdon et al. 2008, Yasukawa et al. 2008). More often, the application of management practices in impacted habitats -both terrestrial and aquatic- is hampered by the fact that even minor alterations in the environment may have a pronounced effect over the relatively lengthy life cycle of the animals (Musick 1999, Plummer et al. 2008). While, some freshwater chelonian species are relatively tolerant of such impacts, others may suffer profound modifications in their population density or structure (Spinks et al. 2003, Marchand \& Litvaitis 2004, Hartwig \& Kiviat 2007, Yasukawa et al. 2008). Studies of habitat use and population size structure in pristine or lightly-impacted habitats may thus provide important insights into the natural distribution patterns and impact tolerance of freshwater chelonians.

The spot-legged turtle, Rhinoclemmys punctularia punctularia (Daudin 1801), is a widely-distributed, semi-aquatic chelonian known locally in Pará state as the "perema" or "aperema". The species is found in the lowlands of Eastern Venezuela, Trinidad and the Guyanas, and in Northern Brazil (Fretey et al. 1977, Pritchard \& Trebbau 1984, RuedaAlmanacid et al. 2007). This is the only taxon of the family Geoemydidae found in Brazil, where it occurs in the Amazon basin, in the states of Amazonas, Amapá, Maranhão, Tocantins and coastal areas of Pará, with one doubtful record from Rio Grande do Norte (Fretey et al. 1977, Pritchard 1979, Pritchard \& Trebbau 1984, Rueda-Almanacid et al. 2007, Dornast et al. 2011). Relatively few data are available on R. p. punctularia (Fretey et al. 1977, Pritchard \& Trebbau 1984, Bonini-Domingos et al. 2007), and most of the published studies have focused on the species' taxonomy, geographic distribution, and captivity behavior (Barros et al. 1975, Bickham \& Baker 1976, Fretey 1977, Ernst 1978, Pritchard 1979, Carr \& Bickham 1986, Fretey et al. 1977, Ernst \& Barbour 1989, Spinks et al 2004, Le \& McCord 2008, Rhodin \& Carr 2009).

We investigated the habitat use by $R . p$. punctularia at Algodoal-Maiandeua Island, a protected area in state of Pará, Northern Brazil. Differences in the use of the available habitats were analyzed in the context of their physicalchemical characteristics (salinity, $\mathrm{pH}$, water temperature and air temperature), geomorphology, vegetation, and substrate type. The size structure and sex ratios of the R.p.punctularia populations were also compared among sites.

\section{MATERIALS AND METHODS}

Study area: The island of AlgodoalMaiandeua, in the municipality of Maracanã, with $32.5 \mathrm{~km}^{2}$, is located in the Northeastern corner of the Brazilian state of Pará $\left(00^{\circ} 34^{\prime} \mathrm{S}-47^{\circ} 31^{\prime} \mathrm{W}\right)$. The island is a protection area since 1990 and it presents a variety of different habitats, including sandbanks or "restingas" (recently-formed environments formed by plant communities influenced by marine and fluvial variables: Freire 1990, Sugiyama 1998), mangroves, dune fields, permanent and temporary lakes, igapó (seasonally flooded or permanently flooded forest), as well as terra firme habitat (well-developed forest on dry land in the center of the island).

The climate is characterized by a marked rainy season between December and May, and much lower precipitation levels during the rest of the year, with mean annual precipitation of 3000mm (Ruivo et al. 2005). Ambient temperatures are inversely related to precipitation 
levels, with the highest temperatures being observed during the dry season, and an annual mean of $27^{\circ} \mathrm{C}$ (Ruivo et al. 2005).

Sampling: Two field trips were conducted to collect data on habitat use of $R$. p. punctularia on Algodoal-Maiandeua Island. One excursion took place during the rainy season, in March and April, while the second was during the dry season (August and September) both in 2009, with a total of 40 days in the field. During these excursions, four distinct habitats were surveyed: coastal plain lake, flooded forest (igapó), interdunal lakes, and tidal channels (Table 1). Two independent sites (replicates) were selected for each type of habitat (Fig. 1), taking care to ensure that both sites were similar in structure and representative of the habitat category. Turtles were captured using hoop nets baited with dried fish (Vogt 1980). The traps are made of three iron rings, with a funnel-type entrance, set in a $50 \mathrm{~mm}$ mesh net. The rings varied in diameter from $600-1500 \mathrm{~mm}$, according to the depth of the water in the habitat being surveyed, in order to guarantee that the trap remained partly above the surface of the water, to ensure that the trapped animals would not drown. The diameter of the entrance varied in size from $150-250 \mathrm{~mm}$.

The traps were set at a distance of approximately $30 \mathrm{~m}$ from each other, along the principal axis of the habitat. The number of traps per habitat was proportional to its relative size, i.e. a proportional stratified sampling procedure (Andrew \& Mapstone 1987). All traps were installed for a continuous period of

TABLE 1

Physical and vegetation characteristics for the different habitats sampled on Algodoal-Maiandeua Island in Maracanã, Pará, in 2009

\begin{tabular}{|c|c|c|}
\hline Habitat & Description & Vegetation \\
\hline IDL & $\begin{array}{l}\text { Lakes formed in the depressions between } \\
\text { dunes, surrounded by restinga vegetation. } \\
\text { The substrate is mainly sandy, with patches } \\
\text { of decaying organic material }(3-30 \mathrm{~cm} \text { deep) } \\
\text { resulting from the decomposition of the } \\
\text { macrophytes in the lake. }\end{array}$ & $\begin{array}{l}\text { Conocarpus sp. (Combretaceae), } \\
\text { Chysobalanus sp. (Chrysobalanaceae), } \\
\text { Ryzophora sp. (Rhizophoraceae), } \\
\text { Nymphaea } \text { sp. (Nymphaeaceae), } \\
\text { Annona } \text { sp. (Annonaceae), } \\
\text { Avicennia } \text { sp. (Acanthaceae) }\end{array}$ \\
\hline IG & $\begin{array}{l}\text { Low-lying terrain adjacent to streams which is } \\
\text { flooded during the rainy season, and covered } \\
\text { with medium- to large-sized trees. The substrate } \\
\text { is sandy-clayey, covered with decomposing leaf litter. }\end{array}$ & $\begin{array}{l}\text { Mauritia flexuosa (Arecaceae), } \\
\text { Euterpe oleracea (Arecaceae), } \\
\text { Carapa guianensis (Meliaceae), } \\
\text { Bactris bidentula (Arecaceae), } \\
\text { Desmoncus sp. (Arecaceae), } \\
\text { Attalea dubia (Arecaceae), } \\
\text { Astrocaryum vulgare (Arecaceae) }\end{array}$ \\
\hline CPL & $\begin{array}{l}\text { Lakes on the coastal plain, surrounded by } \\
\text { restingas and permanent patches of forest. } \\
\text { Substrate formed mainly by sand, with a layer } \\
\text { of decomposing organic material, of } 3 \mathrm{~cm} \text { to } 100 \mathrm{~cm} \text { in depth. }\end{array}$ & $\begin{array}{l}\text { Anacardium sp. (Anacardiaceae), } \\
\text { Chysobalanus sp., } \\
\text { Laguncularia sp. (Combretaceae), } \\
\text { Nymphaea sp., Annona sp. and, } \\
\text { in some areas, stands of Ryzophora sp. }\end{array}$ \\
\hline $\mathrm{TC}$ & $\begin{array}{l}\text { Natural channels formed on the coastal plain, } \\
\text { which are sustained by the flow of the local } \\
\text { macrotidal currents. The substrate is mainly } \\
\text { clay, with some silt and sand. }\end{array}$ & $\begin{array}{l}\text { Ryzophora sp., } \\
\text { Laguncularia } \mathrm{sp} ., \\
\text { Conocarpus } \mathrm{sp} . \\
\text { Avicennia } \mathrm{sp} .\end{array}$ \\
\hline
\end{tabular}

*IDL= interdunal lake; $\mathrm{IG}=$ igapó $; \mathrm{CPL}=$ coastal plain lake; $\mathrm{TC}=$ tidal channel. 


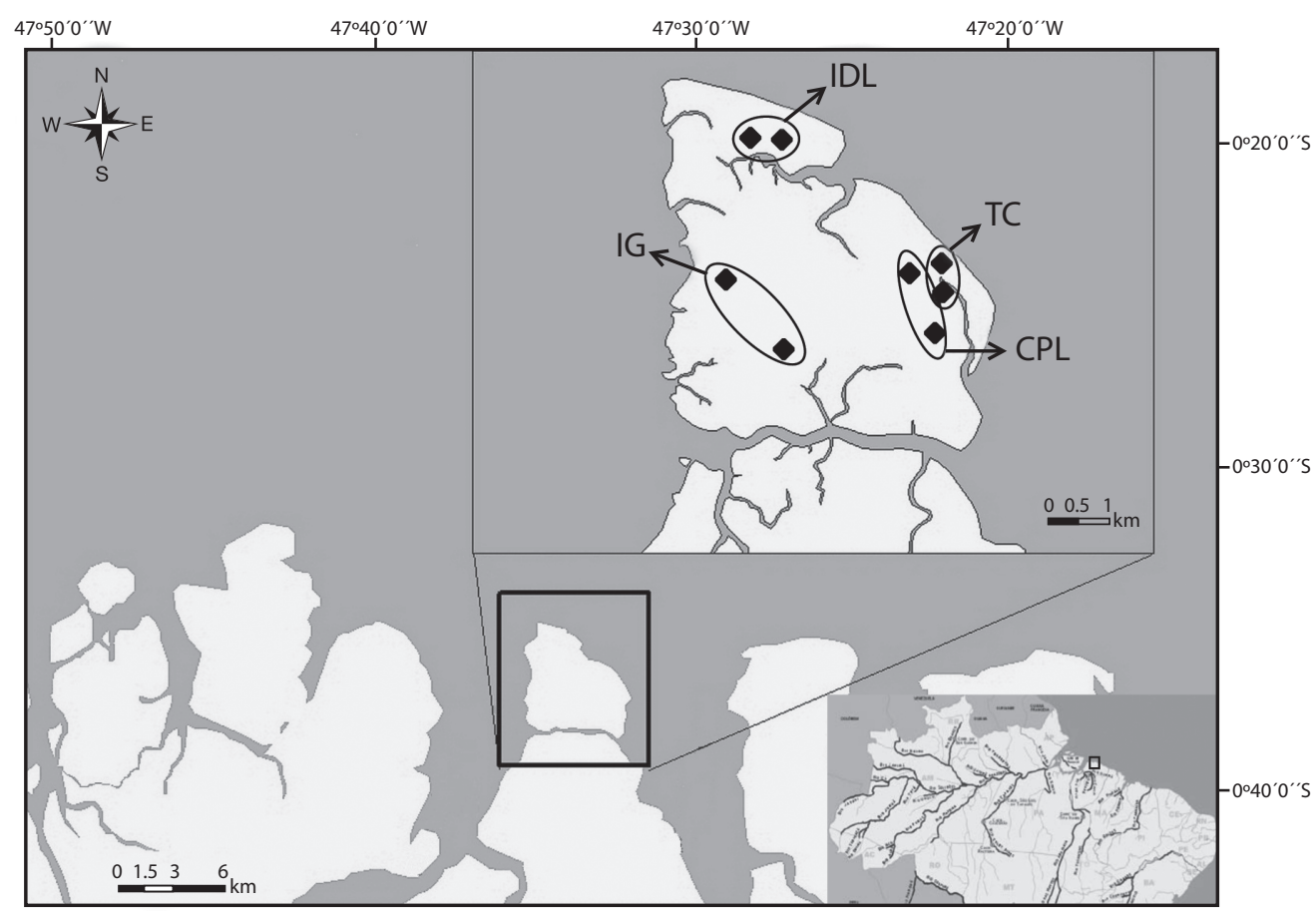

Fig. 1. Sampling points on Algodoal-Maiandeua Island, Pará, Brazil, monitored during the present study. IDL=interdunal lake; IG=igapó; $\mathrm{CPL}=$ coastal plain lake; TC=tidal channel.

approximately $49 \mathrm{~h}$, and were checked every $12 \mathrm{~h}$, at dawn and dusk. At each site, we recorded the salinity, $\mathrm{pH}$ (with a multi-parameter), and the temperature of the water and the air, at $9 \mathrm{~h}$ am, using a digital thermometer. The characteristics of each habitat, including the type of vegetation at the water's edge, the presence of aquatic macrophytes and the type of substrate were recorded. For the analysis of population structure, additional data were included taken in March and August, 2008, with a total of 20 days in the field, when the same type of hoop trap was used, but sampling effort was not standardized. Additionally, in May, 2009, hoop traps were installed in temporary pools formed during the rainy season.

The captured animals were measured, and sexed based on their body size and secondary sexual traits, such as the shorter carapace and slight plastral in the males, and the thicker tail in the females (Ernst \& Barbour 1989). Animals in which these traits were not well-defined were classified as juveniles. Body size was evaluated by the straight carapace length (SCL), which was measured using a metal caliper (precision 1mm). Each individual was marked with holes in the marginal shields (Cagle 1939), into which numbered plastic floy cinch-up tags were fixed. Whenever possible, feces were obtained from the captured animals and examined for the identification of digested food items, such as seeds. Once measured and processed, the animals were released at the sites where they were captured. Informal interviews with local fishermen and other inhabitants of the island were conducted occasionally in order to obtain additional information on the behavior of $R$. p. punctularia.

The possible effects of physical-chemical factors on differences among samples were tested using an analysis of similarity (ANOSIM). Following the identification of distinct groups, a similarity percentages analysis (SIMPER) was applied for the identification of the 
relative importance of each factor in the formation of the groups. The samples were then plotted using multidimensional scaling (MDS), in which the distance between samples was proportional to their similarity. Stress values of less than 0.2 were considered acceptable, and those lower than 0.1 ideal (Clarke \& Gorley 2005). Multiple regression analysis was used to evaluate the possible relationship between environmental (independent) variables (air and water temperature, salinity, and $\mathrm{pH}$ ) and capture rates (dependent variable) (Ayres et al. 2007).

Seasonal variation in habitat use was analyzed based on capture per unit of effort (CPUE). This capture rate (number of individuals per hour) was calculated by dividing the number of individuals captured in each trap by the duration of the period during which the trap was in the water. Differences in capture rates between habitats (comparing only the habitats in which the species was observed) and seasons were assessed using the Mann-Whitney test (Ayres et al. 2007).

The sex ratio was compared between habitats and seasons using chi-square (contingency tables). The Mann-Whitney test was used to evaluate the difference in body size between males and females and between habitats (Ayres et al. 2007). Univariate tests were run in the BioEstat 5.0 program (Ayres et al. 2007), whereas the multivariate analyses were conducted in the Primer 6 program (Clarke \& Gorley 2005). In both cases, $\alpha<0.05$ was considered significant. The SCL values were plotted in a dot density graph using SYSTAT 10.2 (Wilkinson 1990).

\section{RESULTS}

Habitat use: $R$. $p$. punctularia were captured only in the coastal plain lakes, igapós, and occasionally, in the temporary pools that form in adjacent areas to the coastal plain lakes during the rainy season. The species was not captured in the tidal channels or interdunal lakes. Despite this finding, some of local residents reported that individuals may be found sporadically in both habitats, and that a specimen had been captured in the tidal fishing weirs on one of the island's beaches, in the vicinity of the tidal channels surveyed during the present study.

According to local residents, the turtles that inhabit the lakes of the coastal plain may disperse to the temporary pools formed around the lakes during the rainy season, travelling distances of 300-600m. Some individuals may also be swept into the channels when the lakes overflow. Movements between lakes of up to $500 \mathrm{~m}$ have also been observed during the dry season, when some of these bodies of water dry up. The reports of the local residents were confirmed by the capture of seven turtles in the temporary pools during the rainy season. In addition, one individual that had been captured and marked in a lake on the coastal plain was recaptured in a neighboring lake during the dry season following the drying up of the former.

The composition of the vegetation surrounding the interdunal and coastal lakes is very similar. However, the vegetation of the tidal channels and igapós is quite distinct, with characteristic plant species. These habitats are also geomorphologically distinct (Table 1).

The physical-chemical parameters varied significantly among habitats (ANOSIM, $\mathrm{p}=0.0001$ ). The MDS analysis (stress $=0.1$ ) separated the habitats into two main groups, one formed exclusively by the tidal channels, and the other by the remaining three habitats (Fig. 2). Salinity was the principal factor contributing to the formation of these two groups (Table 2). The tidal channels were distinct from other environments due to their much higher salinity and $\mathrm{pH}$ (Table 3), whereas all the other habitats were relatively similar with regard to these variables. Capture rates were also affected only by salinity, and $R$. p . punctularia was not captured in areas in which salinity was greater than zero (linear multiple regression: $\mathrm{r}=0.18, \mathrm{t}=-2.0295, \mathrm{p}=0.04)$.

Population structure: A total of 169 specimens of $R$. p. punctularia were captured in 2008 and 2009, of which 14 individuals had been recaptured in Algodoal/Maiandeua Island. Of the 162 individuals analyzed, $45.3 \%$ were 


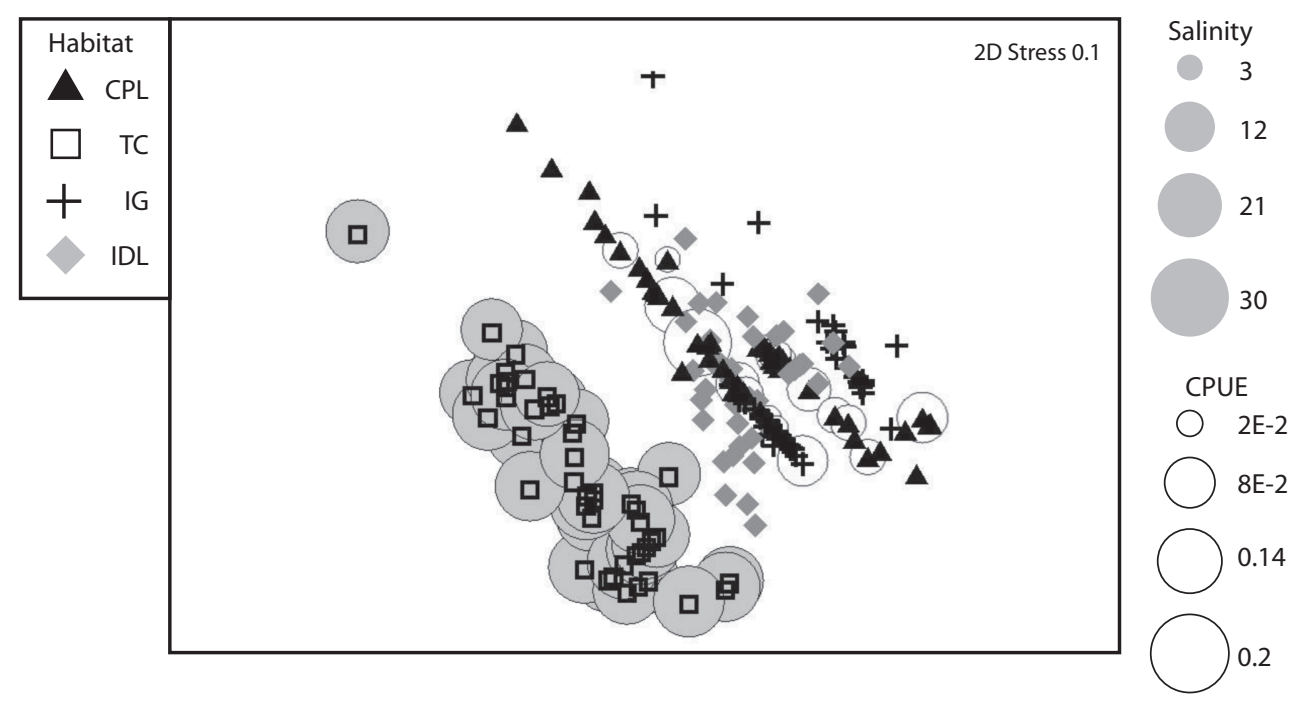

Fig. 2. Multidimensional scaling of the physical-chemical characteristics of the sampling points on Algodoal-Maiandeua Island, Pará, Brazil, representing four different habitat categories. CPUE=catch per unit effort of R. p. punctularia.

TABLE 2

Similarity analyses, and the percent contribution of physical and chemical characteristics that discriminate between habitats on Algodoal-Maiandeua Island, Pará, Brazil

\begin{tabular}{lcccccc}
\multicolumn{1}{r}{ Variable } & \multicolumn{2}{c}{ TC x IG } & \multicolumn{2}{c}{ TC x CPL } & \multicolumn{2}{c}{ TC x IDL } \\
& Contrib\% & Sq.Dist/SD & Contrib\% & Sq.Dist/SD & Contrib\% & Sq.Dist/SD \\
Salinity & 39.05 & 15.57 & 40.53 & 15.57 & 48.5 & 15.57 \\
$\mathrm{pH}$ & 29.11 & 1.04 & 20.12 & 1.01 & 21.22 & 0.84 \\
Air $\left({ }^{\circ} \mathrm{C}\right)$ & 17 & 0.71 & 19.85 & 0.77 & 16.77 & 0.8 \\
Water $\left({ }^{\circ} \mathrm{C}\right)$ & 14.84 & 0.6 & 19.5 & 0.65 & 13.51 & 0.59 \\
\hline
\end{tabular}

* IDL=interdunal lake; IG=igapó; $\mathrm{CPL}=$ coastal plain lake; TC=tidal channel.

* Sq. Dist=Square Distance; SD=Standard Deviation.

TABLE 3

Mean air and water temperature, $\mathrm{pH}$, and salinity in the four habitats surveyed on Algodoal-Maiandeua Island in 2009

\begin{tabular}{lcccc}
\multicolumn{1}{c}{ Variable } & CPL & IDL & IG & TC \\
Air $\left({ }^{\circ} \mathrm{C}\right)$ & $28.75 \pm 2.48(25-33.7)$ & $27.54 \pm 1.17(25.7-32.5)$ & $27.58 \pm 2.19(25.1-36.6)$ & $30.59 \pm 1.63(27-33.6)$ \\
Water $\left({ }^{\circ} \mathrm{C}\right)$ & $29.02 \pm 2.33(25-35.1)$ & $28.04 \pm 1.24(25.1-31.9)$ & $26.83 \pm 1.26(25.6-32.6)$ & $29.43 \pm 1.73(27-35.1)$ \\
$\mathrm{pH}$ & $5.95 \pm 0.27(4.99-6.6)$ & $6.39 \pm 0.41(6-7.2)$ & $5.29 \pm 0.81(3.7-6.2)$ & $7.07 \pm 0.35(6.8-7.8)$ \\
Salinity $(\mathrm{ppm})$ & 0 & 0 & 0 & $22.04 \pm 2.31(18-26)$ \\
$\mathrm{N}$ & 53 & 50 & 49 & 47 \\
\hline
\end{tabular}

*=Mean \pm standard deviation (range), IDL=interdunal lake; IG=igapó; CPL=coastal plain lake; TC=tidal channel. 
females, $43.2 \%$ males and $11.5 \%$ were juveniles. The sex ratio was lightly biased toward females, but not significantly $\left(X^{2}=0.06\right.$, d.f. $=1$, $\mathrm{p}=0.86$ ). There was also no significant difference in the sex ratio between igapós and coastal lakes $\left(\mathrm{X}^{2}=0.028\right.$, d.f. $\left.=1, \mathrm{p}=0.92\right)$ or between seasons $\left(\mathrm{X}^{2}=2.62\right.$, d.f. $\left.=1, \mathrm{p}=0.15\right)$.

The mean straight carapace length (SCL) of the individuals captured was $173.7 \pm 30.9$ (range 226-77.8mm, $\mathrm{n}=162$ ). The mean value in females was $195.42 \pm 18 \mathrm{~mm}$ (range 143$226 \mathrm{~mm}, \mathrm{n}=68$ ), while it was $167 \pm 12.7 \mathrm{~mm}$ (range $133-197 \mathrm{~mm}, \mathrm{n}=64$ ) in males, and 107.2 \pm 14.8 (range $77-132 \mathrm{~mm}, \mathrm{n}=17$ ) in juveniles (Fig. 3). The females were significantly (Mann-Whitney, U=454.02, $\mathrm{p}=0.0001$ ) larger in size than males. Mean length in coastal plain lakes was $174.7 \pm 30.7 \mathrm{~mm}$ (range: $133-197 \mathrm{~mm}$, $\mathrm{n}=130)$. The majority $(89.5 \%)$ of the individuals captured were adults. In the igapós mean SCL was $166.59 \pm 33.2 \mathrm{~mm}$ (range $77-208 \mathrm{~mm}$, $\mathrm{n}=20$ ), with a slightly reduced proportion of adults $(85.0 \%)$. The difference in SCL between habitats was not significant (Mann-Whitney, $\mathrm{U}=1132$, $\mathrm{p}=0.35$ ).

Most individuals were caught in the coastal plain lakes $(87.7 \%, \mathrm{n}=142)$. Capture rates were significantly higher in the coastal

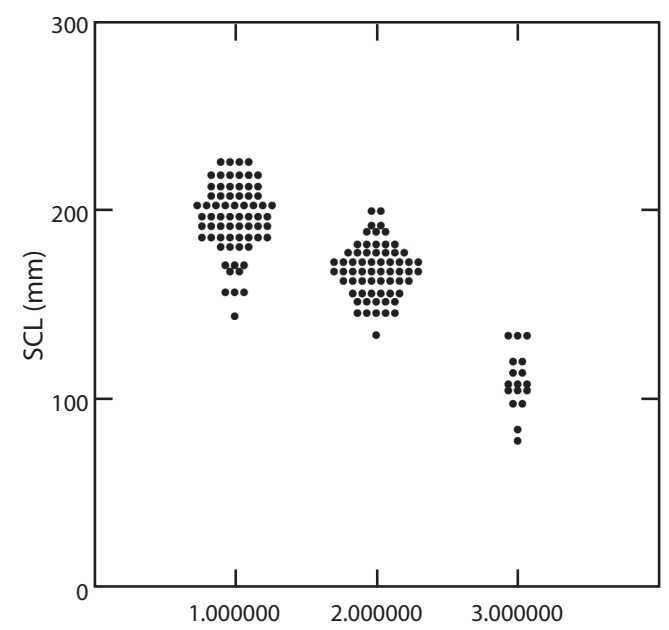

Fig. 3. Distribution of straight carapace lengths (in millimeters) of female, male and juvenile $R$. p. punctularia captured on Algodoal/Maiandeua Island, Pará, Brazil. plain lakes $(0.017 \mathrm{ind} / \mathrm{h})$ in comparison with the igapós (0.0025 ind/h) (Mann-Whitney, $\mathrm{U}=852, \mathrm{p}=0.00012, \mathrm{n}=162)$. Capture rates were apparently higher $(0.0064 \mathrm{ind} / \mathrm{h})$ during the dry season than the wet season $(0.0042$ ind/h) but not significant (Mann-Whitney, $\mathrm{U}=4$ 829, $\mathrm{p}=0.76, \mathrm{n}=199$ ).

Seeds of Annona sp. (Annonacea) and Chrysobalanus sp. (Chrysobalanaceae) were observed in the feces of captured specimens. All other items found in the feces were too decomposed to allow their identification. Local inhabitants also reported that the water lily Nymphaea sp. (Nymphaeaceae), is part of the diet of the spot-legged turtle.

\section{DISCUSSION}

The spot-legged turtle, R. p. punctularia, occurs in a variety of habitats. The species has been observed in coastal swamps, flooded savannas, bodies of water in primary and secondary forests, streams, marshes, lakes and lagoons, temporary pools and, occasionally, in areas far from water (Fretey 1977, Fretey et al. 1977, Rueda-Almonacid et al. 2007, Dornas et al. 2011). On Algodoal-Maiandeua Island, the species was found in igapós, coastal plain lakes, and the temporary pools that form in the vicinity of these lakes during the rainy season. This utilization of a variety of habitats may explain the relatively extensive distribution of the species, which is considered to be a generalist (Pritchard \& Trebbau 1984, Rueda-Almonacid et al. 2007).

While the species was not captured in tidal channels, it seems likely that at least some individuals may reach this habitat occasionally, according to reports from local residents. This indicates that, while the species prefers fresh water, it may have a certain tolerance for seawater, as observed in Pangshura tecta (Gray 1830), a geoemydid found sporadically in estuarine habitats in Bangladesh (Sarker \& Hossain 1997). This tolerance is even more pronounced in the geoemydid Batagur baska (Gray 1831), which is found exclusively in estuarine habitats in Southeast Asia (Sarker \& 
Hossain 1997, Holloway 2003). On AlgodoalMaiandeua Island, the coastal lakes expand during the rainy season, and part of the excess water flows into the tidal channels. It seems likely that, during this period, some individuals may dislocate to the tidal channels.

The lack of specializations for osmoregulation in $R$. p. punctularia, together with the absence of fruit-bearing trees from the tidal channels, may have restricted the exploitation of the environment by this turtle (Dunson \& Mazzotti 1989). Like the tidal channels on Algodoal-Maiandeua Island, the estuarine habitats occupied by B. b. baska in Southeast Asia are dominated by mangrove forest, although the fruit of one tree species -Sonneratia caseolaris (Lythraceae)- is part of the diet of this turtle (Holloway 2003), although no fruiting trees are found in the tidal channels of Algodoal/Maiandeua Island. An additional factor that may have influenced the absence $R$. p. punctularia from the tidal channels in the present study is the presence of strong tidal currents typical of the region's macrotides (DHN 2004), which may be an obstacle to a semiaquatic species (Rashid \& Swingland 1997) such as $R$. punctularia.

An apparent preference for water with low $\mathrm{pH}$ has also been recorded in R.p. punctularia by Ernst \& Barbour (1989), who captured specimens in bodies of relatively acidic water. However, Pritchard \& Trebbau (1984) captured specimens in both acidic and alkaline water. Together with the results of the present study, this evidence indicates that $R$. p. punctularia may inhabit aquatic habitats with widely varying $\mathrm{pH}$ values within its geographic distribution.

The interdunal lakes in the present study were surrounded by sandbank vegetation similar to that found in the vicinity of the coastal lakes, characterized by plant species such as Annona sp. and Chrysobalanus sp., which were also found in most of the species fecal samples collected during the study. Although the interdunal lakes appear to be a favorable environment for $R$. p . punctularia, no specimens were collected in this habitat during the present study. However, a local fisherman, who lives near an interdunal lake, provided us with a turtle captured on a beach in this area. While the dunes may represent barriers to dispersal, this environment may be used in a secondary fashion by the turtles. Barreto et al. (2009) observed Trachemys adiutrix (Vanzolini 1995) and Kinosternon scorpioides (Linnaeus 1766) in an area of dunes on Curupu island, in the Brazilian state of Maranhão, while Fretey (1977) observed spot-legged turtles in areas isolated from bodies of water.

The recapture of marked individuals confirmed the reports of local residents, who asserted that the species dislocate between coastal plain lakes, temporary pools. Movements were recorded during the height of both the rainy and the dry seasons, indicating the influence of hydrological cycles and variation in water levels. A similar pattern has been recorded for Terrapene carolina carolina (Linnaeus 1758), which moves to alternative habitats during periods of low precipitation and high temperatures (Donaldson \& Echternacht 2005). However, while some individuals moved to new habitats during the dry season, others sought refuge by burying themselves in the muddy substrate of coastal plain lakes. A number of studies have recorded periods of inactivity, classified as aestivation, in freshwater chelonians (Bury 1979, Litzgus et al. 1999, Pereira et al. 2007). In the Northern hemisphere, Clemmys guttata (Schneider 1792) engages in this type of behavior as a way of protecting itself from the cold during the least favorable periods of the winter (Litzgus et al. 1999). K. scorpioides also presents an aestivation behavior during the dry season in the state of Maranhão, Brazil, when the animals bury themselves, presumably to avoid dehydration (Pereira et al. 2007). A similar strategy may be adopted by $R$. $p$. punctularia, when lakes dry out during the less rainy months.

While no anthropogenic impacts were observed in the proximity of the igapós during the present study period, some local residents reported that these areas have been burned off in the past for agriculture and cattle grazing. The loss of habitat is considered to be the 
principal factor in the decline of chelonian populations worldwide (Sarker \& Hossain 1997, Freitas et al. 2003, Moll \& Moll 2004, Browne \& Hecnar 2007). Habitat changes could impact the R. p. punctularia population of AlgodoalMaiandeua Island, and explain lower catches in igapós. Nevertheless, further studies will be required in order to fully understand the alterations caused to this population in this locality.

The sporadic capture of individuals in temporary pools during the wet season is a pattern similar to that recorded in some other studies of freshwater turtles. Kennett \& Georges (1990) concluded that such environments provide relatively rich dietary resources and conditions favorable to growth and reproduction, as observed in Chelodina longicollis (Shaw 1794) in Australia. Morenia petersi, a geoemydid found in Bangladesh, also uses temporary pools (Sarker \& Hossain 1997).

The lack of seasonal variation in the present study may have been related to small variation in mean temperature, characteristic of equatorial environments, in contrast to a more temperate climate in other sites (Souza \& Abe 1997, Donaldson \& Echternacht 2005). Webb (1962 apud Bury 1979) found that the activity of populations of Apalone spinifera (LeSueur 1827) at relatively high latitudes was restricted to only a few months each year, whereas those at lower latitudes were active throughout the year.

The use of different techniques for the capture of different species or sexes of freshwater chelonians and in different habitats may be reflected in distinct proportions of juveniles, varying from $0 \%$ to $70 \%$ (Bury 1979). In general, however, most studies of freshwater chelonians have recorded a larger proportion of adults than juveniles (Fachín-Terán et al. 2003, Litzgus \& Mousseau 2004, Ruane et al. 2008). The population structure may also vary across habitats, resources, and seasonal gradients, as well as over the course of time (Bodie \& Semlitsch 2000). In the specific case of $R$. $p$. punctularia, in addition to habitat selectivity, a factor that may account for the low capture rate of juveniles is the relative abundance of refuges with restricted access, which impede capture.

Our results reconfirm the occurrence of sexual dimorphism in body size in this species (Fretey 1977, Pritchard \& Trebbau 1984). In some species of turtle, sexual dimorphism appears to play an important role in intraspecific interactions, primarily by reducing competition (Stephens \& Wiens 2009). The larger size of the females may enhance reproductive success, in particular through the production of clutches of larger size (Bury 1979, Ruane et al. 2008).

As for most other species, habitat selection and use may be influenced by both biotic and abiotic factors, such as the availability of dietary resources, salinity, and the presence of dunes (MacArthur \& Levins 1964, Block \& Brennan 1993, Kraussman 1999). On Algodoal-Maiandeua Island, $R$. p . punctularia was found in igapós, coastal plain lakes and, occasionally, in temporary pools. Population density was higher in the coastal plain lakes. Thus, this habitat seems to be a key habitat for the conservation of this species in the island.

The results of the present study contributed to a better understanding of the ecology of $R$. p p punctularia. These data may provide an important baseline for the development of management strategies (Burke et al. 2000) for the species on Algodoal/Maiandeua Island, which is a state conservation unit designated for the protection of local biological diversity and uphold the sustainability of the exploitation of natural resources.

\section{ACKNOWLEDGMENTS}

We are grateful to the people who helped with data collection, and the residents of the community of Fortalezinha. The Pará State Environment Secretary authorized this study in the APA Algodoal-Maiandeua through license number 014/09. We also thank the PIT/PA project for financial support. 


\section{RESUMEN}

Rhinoclemmys punctularia punctularia es un quelonio semi-acuático, con amplia distribución geográfica. El presente trabajo analiza la densidad relativa, proporción sexual y el uso de hábitat de esta especie en la isla de Algodoal-Maiandeua, en el litoral Norte de Brasil. Cuatro hábitats distintos fueron muestreados durante los períodos de lluvias y seco de 2009, en donde se utilizaron trampas de aro. Muestras de 2008 (marzo-agosto) también se emplearon para el análisis de la estructura de la población. Asimismo, fueron encontrados 169 ejemplares en el bosque inundado, lagunas de tierras bajas y, ocasionalmente, en lagunas temporales. Las tasas de captura fueron más altas en las lagunas costeras, posiblemente debido a la mayor disponibilidad de frutos, que sirven de alimento para esta especie. De las variables físico-químicas, la salinidad fue el único factor que se correlaciona inversamente con las tasas de captura. La proporción de sexos fue ligeramente superior en las hembras, pero no varió entre los hábitats o período del año. El tamaño promedio de los individuos fue mayor en las hembras, pero no varió entre hábitats. Los factores ambientales, como la disponibilidad de alimentos, la baja salinidad y la poca corriente, probablemente hayan favorecido la selección y el uso de estos hábitats por R.p. punctularia.

Palabras clave: quelonio, ecología, Rhinoclemmys punctularia punctularia, Amazonía.

\section{REFERENCES}

Andrew, N.L. \& B.D. Mapstone. 1987. Sampling and the description of spatial pattern in marine ecology. Oceanogr. Mar. Biol., Annu. Rev. 25: 39-90.

Ayres, M., M. Ayres Jr., D.L. Ayres \& A.S. Santos. 2007. BioEstat 5.0 Aplicações estatísticas nas áreas das ciências biológicas e médicas. IDSM/MCT/CNPq, Pará, Brasil.

Barreto, L., L.C. Lima \& S. Barbosa. 2009. Observations on the ecology of Trachemys adiutrix and Kinosternon scorpioides on Curupu Island, Brazil. Herp. Rev. 40: 283-286.

Barros, R.B., M.M. Sampaio, M.F. Assis, M. Ayres \& O. Cunha. 1975. Karyological study of Geoemyda punctularia punctularia (Daudin, 1802) from the Amazon region of Brazil (Chelonia, Emydidae). Acta Amaz. 5: 95-96.

Bickham, J.W. \& R.J. Baker. 1976. Karyotypes of some neotropical turtles. Copeia 4: 703-708.

Block, W.M. \& L.A. Brennan. 1993. The habitat concept in ornithology: theory and applications, p. 35-91.
In D.M. Power (ed.). Current Ornithology Vol. 11. Plenum, New York, USA.

Bodie, J.R. \& R.D. Semlistsch. 2000. Spatial and temporal use floodplain habitats by lentic and lotic species of aquatic turtle. Oecologia 122: 138-146.

Bonini-Domingos, C.R., M.B. Silva, R.M. Romero, P.J.A. Zamaro, L.S. Ondei, C.E.S. Zago, S.B. Moreira \& C.G. Salgado. 2007. Description of electrophoretic and chromatographic hemoglobin profile of Rhinoclemmys punctularia. Genet. Mol. Res. 6: 415-421.

Boyer, D.R. 1965. Ecology of the basking habitat in turtle. Ecology 46: 99-118.

Browne, C.L. \& S.J. Hecnar. 2007. Species loss and shifting populations structure of freshwater turtle despite habitat protection. Biol. Conservat. 38: 421-429.

Burke, V.J., J.E. Lovich \& J.W. Gibbons 2000. Conservation of freshwater turtles, p. 156-179. In M.W. Klemens (ed.). Turtle conservation. Smithsonian Institution, Washington D.C., USA.

Bury, R.B. 1979. Population ecology of freshwater turtles, p. 571-602. In M. Harless \& H. Morlock (eds.). Turtles: Perspectives and Research. John, New York, USA.

Cagle, F.R. 1939. A system of marking turtles for future identification. Copeia 3: 170-173.

Carr, J.L. \& A. Giraldo. 2009. Rhinoclemmys nasuta (Boulenger 1902) large-nosed wood turtle, Chocoan river turtle. Conservation Biology of Freshwater Turtles and Tortoises 5: 034.1-034.5.

Clarke, K.R \& R.N Gorley. 2005. PRIMER v6: User Manual/Tutorial. PRIMER-E, Plymouth, USA.

Congdon, J.D., T.E. Graham, T.E. Herman, J.W. Lang, M.J. Pappas \& B.J. Brecke. 2008. Emydoidea blandingii (Holbrook 1838) - blanding's turtle. Conservation Biology of Freshwater Turtles and Tortoises, Chelonian Research Monographs 5: 015.1-15.12.

DHN - Departamento de Hidrografia e Navegação. 2004. Tábuas de marés para 1994. Costa do Brasil e alguns portos estrangeiros. DHN, Rio de Janeiro, Brasil.

Donaldson, B.M. \& A. Echternacht. 2005. Aquatic habitat use relative to home range and seasonal movement of eastern box turtle (Terrapene Carolina Carolina: Emydidae) in eastern Tennessee. J. Herpetol. 39: 284-287.

Dornas, T., A. Malvasio \& R.T. Pinheiro. 2011. Reptilia, Testudines, Geoemydidae, Rhinoclemmys punctularia 
(Daudin, 1802): New geographical distribution and first record for the state of Tocantins, Brazil. Check List 7: 49-51 (São Paulo. Online, www.checklist.org. br/getpdf?NGD144-10).

Dunson, W.A. \& F.J. Mazzotti. 1989. Salinity as a limiting factor in the distribution of reptiles in Florida Bay: a theory for the estuarine origin of marine snakes and turtles. Bull. Mar. Sci. 44: 229-244.

Ernst, C.H. 1978. A revision of the Neotropical turtle genus Callopsis (Testudines: Emydidae: Batagurinae). Herpetologica 34: 113-134.

Ernst, C.H.E. \& R.W. Barbour. 1989. Turtles of the world. Smithsonian Institute, Washington, USA.

Fachín-Terán, A., R.C. Vogt \& J.B. Thorbjarnarson. 2003. Estrutura populacional, razão sexual e abundância de Podocnemis sextuberculata (Testudines, Podocnemididae) na Reserva de Desenvolvimento Sustentável Mamirauá, Amazonas, Brasil. Phyllomedusa 2: 43-63.

Freire, M.S.B. 1990. Levantamento florístico do Parque Estadual das Dunas de Natal, Acta Botanica Brasilica 4: 41-59.

Freitas, C.A., F.R. Scarano \& D.D. Biesboer. 2003. Consequences of habitat fragmentation on age structure and life history in a tortoise population. Biotropica 35: 550-555.

Fretey, J. 1977. Les Chelonies de Guyane Françoise: etude préliminaire. Tese. Université Paris, Paris, França.

Fretey, J., M.S. Hoogmoed \& J. Lescure. 1977. Estude taxinomique de Rhinoclemmys punctularia punctularia (Daudin) (Testudinata, Emydidae). Zool. Meded. 52: 63-80.

Gibbons, J.W., D.E. Scott, T.J. Ryan, K.A. Buhlmann, T.D. Tuberville, B.S. Metts, J.L. Greene, T. Mills, Y. Leiden, S. Poppy \& C.T. Winne. 2000. The global decline of reptiles, déjàvu amphibians. BioScience 50: 653-666.

Hartwig, T.S. \& E. Kiviat. 2007. Microhabitat association of blanding's turtles in natural and constructed wetlands in Southeastern New York. J. Wildl. Manag. 71: 576-582.

Heppell, S.S. \& L.B. Crowder. 1996. Models to evaluate headstarting as a management tool for long-lived turtles. J. Appl. Ecol. 6: 556-565.

Holloway, R.H.P. 2003. Natural history notes on the river terrapin Batagur baska (Gray, 1831) in Cambodia.
Research Development Program Report. Wildlife Conservation Society, New York, USA.

Kennett, R.M. \& A. Georges. 1990. Habitat utilization and its relationship to growth and reproduction of the eastern long-necked turtle, Chelodina longicollis (Testudinata: Chelidae), from Australia. Herpetologica 46: 22-33.

Klemens, M.W. 2000. Introduction, p. 1-4. In M.W. Klemens (ed.). Turtle conservation. Smithsonian Institution, Washington, USA.

Kraussman, P.R. 1999. Some basic principles of habitat use, p. 85-90. In K. Launchbaugh, K. Saunders \& J. Mosley (eds.). Grazing Behaviour of Livestock and Wildlife. Moscow, Idaho, USA.

Le, M. \& W.P. Mccord. 2008. Phylogenetic relationships and biogeographical history of the genus Rhinoclemmys (Fitzinger, 1835) and the monophyly of the turtle family Geoemydidae (Testudines: Testudinoidea). Zool. J. Linn. Soc. 153: 751-767.

Litzgus, J.D. \& T.A. Mousseau. 2004. Demography of a southern population of the spotted turtle (Clemmys guttata). Southeastern Nat. 3: 391-400.

Litzgus, J.D., J.P. Constanzo, R.J. Brooks \& R.E. Lee. 1999. Phenology and ecology of hibernation in spotted turtle (Clemmys guttata) near the northern limit of their range. Can. J. Zool. 77: 1348-1357.

Macarthur, R. \& R. Levins. 1964. Competition, habitat selection, and character displacement in a patchy environment. Zoology 51: 1207-1210.

Marchand, M.N. \& J.A. Litvaitis. 2004. Effects of features and landscape composition on the populations structure of a common aquatic turtle in a region undergoing rapid development. Conservat. Biol. 18: 758-767.

Moll, D. \& E.O. Moll. 2004. The ecology, exploitation, and conservation of river turtles. Oxford, New York, USA.

Musick, J.A. 1999. Ecology and conservation of long-lived marine animals. Am. Fish. Soc. Symp. 23: 1-10.

Pereira, L.A., A.L. Sousa, M.V.J. Cutrim \& E.G. Moreira. 2007. Características ecológicas do habitat de Kinosternon scorpioides scorpioides Linnaeus, 1766 (Reptilia, Chelonia, Kinosternidae) no município de São Bento-Baixada Maranhense (Maranhão, Brasil). Boletim do Laboratório de Hidrobiologia 20: 9-14.

Plummer, M.V., D.G. Krementz, L.A. Powell \& N.E. Mills. 2008. Effects of habitat disturbance on survival rates of softshell turtles (Apalone spnifera) in urban stream. J. Herpetol. 42: 555-563. 
Portal, R.R., M.A.S. Lima, V.L.F. Luz, Y.S.L.B. Bataus \& I.J Reis. 2002. Espécies vegetais utilizadas na alimentação de Podocnemis unifilis, Troschel 1948 (Reptilia, Testudinae, Pelomedusidae) na região do PracuúbaAmapá-Brasil. Ciência Animal Bras. 3: 11-19.

Pritchard, P.C.H. \& P. Trebbau. 1984. The Turtles of Venezuela. Society for the Study of Amphibians and Reptiles, Oxford, United Kingdom.

Pritchard, P.C.H. 1979. Encyclopedia of turtles. T.F.H., New Jersey, USA.

Rashid, S.M.A \& I.R. Swingland. 1997. On the ecology of some freshwater turtle in Bangladesh, p. 225-245. In J. Van Abbema (ed.). Proc. Conservation Restoration and Management of Tortoise and turtles. An Int. Conf. Turtle and Tortoise Society, USA.

Rhodin, A.G.J. \& J.L. Carr. 2009. A quarter millennium of uses and misuses of the turtle name Testudo scabra: identification of the type specimens of T. scabra Linnaeus 1758 (= Rhinoclemmys punctularia) and T. scripta Thunberg in Schoepff 1792 (= Trachemys scripta scripta). Zootaxa 2226: 1-18.

Ruane, S., S.A. Dinkelacker \& J.B. Iverson. 2008. Demographic and reproductive traits of blanding's turtles, Emydoidea blandingii, at the western edge of the species range. Copeia 4: 771-779.

Rueda-Almonacid, J.V., J.L. Carr, R.A. Mittermeier, J.V. Rodríguez-Mahecha, R.B. Mast, R.C. Vogt, A.G.J. Rhodin, J. Ossa-Velásquez, J.N. Rueda \& C.G. Mittermeier. 2007. Las tortugas y los cocodrilianos de los países andinos del trópico. Serie de guías tropicales de campo $\mathrm{N}^{\circ} 6$. Panamericana, Bogotá, Colombia.

Ruivo, M.L.P., I.G. Amaral, M.P.S. Faro, E.L.C. Ribeiro, A.L.S. Guedes \& M.M.L.S. Santos. 2005. Caracterização Química da manta orgânica leve em diferentes tipos de solo em uma topossequência na ilha de Algodoal/Maiandeua, PA. Boletim do Museu Paraense Emílio Goeldi 1: 227-234.
Sarker, S.U. \& L. Hossain. 1997. Populations and habitat status of freshwater turtles and tortoises of Bangladesh and their conservation aspects, p. 290-294. In J. Van Abbema (ed.). Proc. Conservation Restoration and Management of Tortoise and turtles. An Int. Conf. Turtle and Tortoise Society, USA.

Souza, F.L. \& A.S. Abe. 1997. Populations structure, activity, and conservation of the neotropical freshwater turtle, Hydromedusa maximiliani, in Brazil. Chel. Conserv. Biol. 2: 521-525.

Spinks, P.Q., G.B. Pauly, J.J. Crayaon \& H.B. Shaffer. 2003. Survival of the western pond turtle (Emys mamorata) in urban California environment. Biol. Conservat. 113: 257-267.

Spinks, P.Q., H.B. Shaffer, J.B. Iverson \& W.P. Mccord. 2004. Phylogenetic hypotheses for the turtle family Geoemydidae. Mol. Phylogenet. Evol. 32: 164-182.

Stephens, P.R. \& J.J. Wiens. 2009. Evolution of sexual size dimorphisms in Emydid turtles: ecological dimorphism, rensch's rule, and sympatric divergence. Evolution 63: 910-925.

Sugiyama, M. 1998. Estudo de florestas da restinga da Ilha do Cardoso, Cananéia, São Paulo, Brasil. Boletim do Instituto de Botânica 11: 119-159.

Vogt, R.C. 1980. New methods for trapping aquatic turtles. Copeia: 368-371.

Webb, R.G. 1962. North American recent sot-shelled turtles (Family Trionychidae). University of Kansas Publications, Museum of Natural History 13: 429-611.

Wilkinson, L. 1990. Systat: The system for statistics. Systat Inc., Evanston, Illinois, USA.

Yasukawa, Y., T. Yabe \& H. Ota. 2008 Mauremys japonica (Temminck and Schlegel 1835) - Japanese pond turtle. Conservation Biology of Freshwater Turtles and Tortoises 5: 1-6. 